(周波数応答による剛性評価)

\title{
Non Destructive Evaluation Method about the Texture of Puffers Meat.
}

\author{
○正 太田博光(水産大) 正 中村 誠(水産大) 正 江副 覚(水産大) \\ 正 森元映治(水産大) 学 寺崎大輔
}

Hiromitsu OHTA, Makoto NAKAMURA, Satoru EZOE, Eiji MORIMOTO, Daisuke TERASAKI Dept. of Ocean Mechanical Engineering, National Fisheries University, 2-7-1, Nagata-honmachi, Shimonoseki.

Key Words: Texture, Frequency Response Function, Puffers Meat, Young's Modules, Visco-Elasticity

\section{1. 緒論}

魚肉のおいしさを支配する因子として色, 香り, 鮮度, 化 学成分量などが知られているが，これらに加えて食感の占め る割合が大きいこともしばしば言われている(1).フグ肉の場 合，旨みに関連する化学成分は微量であり旨みは他の因子に 依存していると考えられる(2)，本研究ではフグ肉の旨みは食 感に依存する部分が大きいと考光食感の力学的特性の1つで ある剛性(弾性)の推定手法を提案している，手法として身欠 き状態のフグ肉に加振器から Sweep 信号を加え, フグ肉表面 に設置した 3 次元加速度ピックアップから周波数応答を測定 することで動剛性に関連する動質量を求めている，推定值の 比較として圧縮試験により求めたフグ肉の縦弾性係数を用い ている．また圧縮を停止した状態から緩和時間を求めること でフグ肉の粘弾性を考察している.

\section{2. 実験方法}

フグ肉は身欠き状態で図 1 に示す測定用ベッドの真空室上 に配置され真空ポンプで吸引することにより測定用ベッドに 固定される. 測定用ベッドは加振器と接続されており Sweep 信号が加えられる．測定では正弦波の Sweep 信号を 0 300 $\mathrm{Hz}$ まで 15.0[s]で掃引している．測定用ベッド中心部分にフ

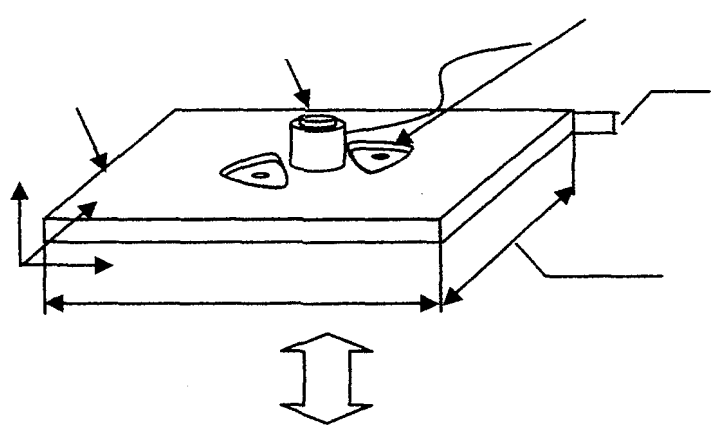

Fig.1 Schematic diagram of measurement bed

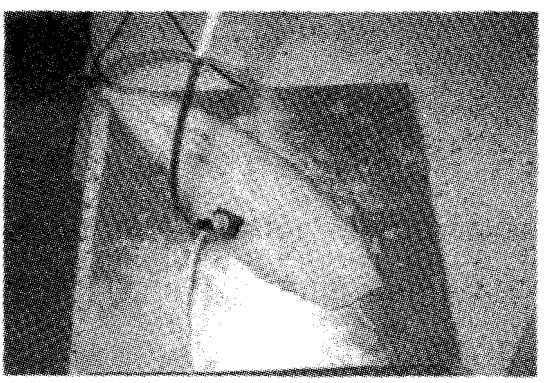

Fig.2 Measurement view

オーストランスデューサが設置されておりフグ肉に作用する 力が測定される.さらにフグ肉表面には吸盤を介して 3 次元 加速度ピックアップが設置されている，吸盤は真空ポンプに より吸引することでフグ肉表面の任意の位置に固定されてい る. 図 2 に測定中の図を示す．解析では周波数応答の動質量 を用いその面積值を算出することで剛性を推定している．そ れぞれの面積值はフグ肉を測定用ベッドに設置していない状 態いわゆる 3 次元加速度ピックアップを直接, 測定用ベッド に設置した状態で算出された動質量の面積値で割られ無次元 化される. 周波数応答測定後,フグ肉は 3 枚に下ろされ, 寸法 $20 \times 20 \times 10[\mathrm{~mm}]$ の大さに統一され、圧縮試験機により加 圧し,弾性領域の伸びから繸弾性係数が求められている．さら に粘性の評価は応力が $1 / \mathrm{e}$ に到達するまでの緩和時間を評価 することにより実施している.今回,測定に使用されたフグ肉 の種類は冷凍養殖トラフグ (冷盖トラと略), 冷凍天然シロサ バフグ（冷天サバと略）の 2 種類である.

\section{3．実験結果および考察}

実験に使用した試験体の個数は冷養トラ 3 個体,冷天サバ 6 個体である. 周波数応答の測定は各個体 10 回,計 90 点実施し た. 縦弾性係数の測定回数は冷養トラで各 33 回, 冷天サバで 計 48 回である. 周波数応答関数は xyz 方向の合成值により 算出される. 図 3,図 4 に冷天サバ,冷養トラの縦弾性係数のヒ ストグラムをそれぞれ示す，冷盖トラでは 50〜90Mpa に約 
$85 \%$ が分布している. 一方，冷天サバでは 34〜 46MPa の間 に約 90\%が分布している.これより泠盖トラの方が鸰天サバ より強度的に強いことが分かる．試験体の形状は同一である ので䬼性も同様に冷養トラの方が冷天サバより高いといえる. 図 5, 図 6 に冷天サバ,冷養トラの緩和時間のヒストグラムを それぞれ示す．冷天サバでは 10２0 秒の間に約 93\%が分布 している. 冷養トラでは 5〜11 秒閒に約 $97 \%$ が分布してお り冷天サバ，冷養トラとの違いが明確に現れている．以上よ り冷養トラは冷天サバより剛性が高く粘性は低いことが分か る.図 7 および図 8 は動質量の面積比に関するヒストグラム を表している，横軸は剛性を示す動質量の面積比, 縦軸は確 率密度関数である. 冷天サバは面積比 $0.3 \sim 0.9$ までに分布し ており冷養トラは面積比 $0.6 〜 1.8$ までに分布している. 傾向 として冷養トラは冷天サバより動質量が高いことから剛性も 高いと推定することができる. 冷天サバでは面積比 $0.6 \sim 0.9$ に約 $23 \%$, 冷天サバでは面積比 $0.6 \sim 0.9$ に約 $34 \%$ が分布し ており，この両者が重なる領域では判別することは困難であ

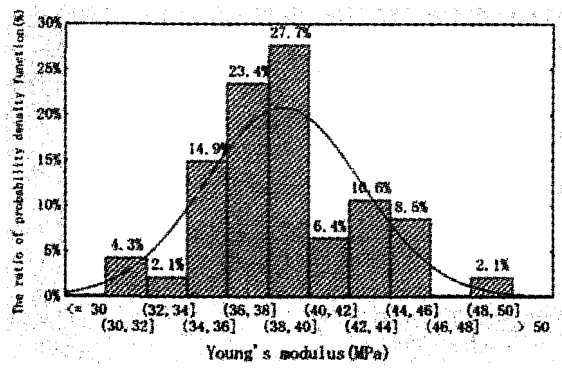

Fig.3 Histogram of Young's modules in the case of Sirosaba puffers

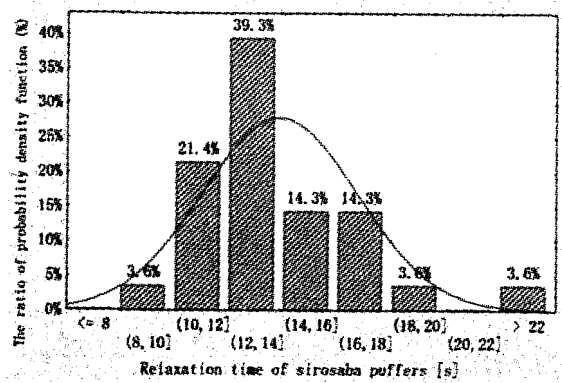

Fig.5 Histogram of relaxation time in the case of Sirosaba puffers

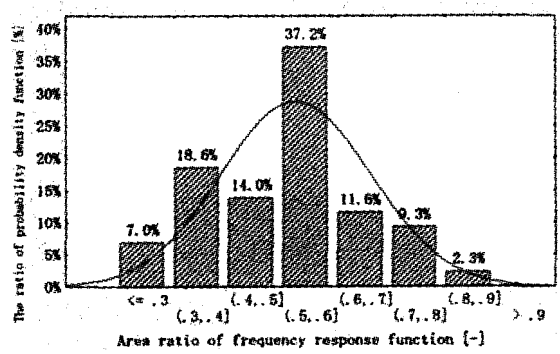

Fig.7 Histogram of area ratio on apparent mass in the case of Sirosaba puffers
ることが分かる。しかしながら提案する周波数応答を利用す る手法を用いることでフグ肉の剛性が非破壊的に推定可能で あることが示された。

\section{4. 結論}

本研究ではフグ肉のおいしさは食感にも依存していると 考え周波数応答を利用した非破壊的かつ短時間で実施できる 食感(剛性)評価法の提案を行い冷凍養殖トラフグ，冷凍天然 シロサバフグを用いて実験的に剛性の推定を行った。同時に フグ肉の圧縮試験を行い縦弾性係数との相関関係を調べ提案 手法の検証を行い,その有効性を確認している.

参考文献

（1）中濱信子他 2 名, おいしさのレオロジー, 弘学出版, (1997), 1-3.

（2）青木義雄, フグの文化, 成山堂書店,(1999),69-80.

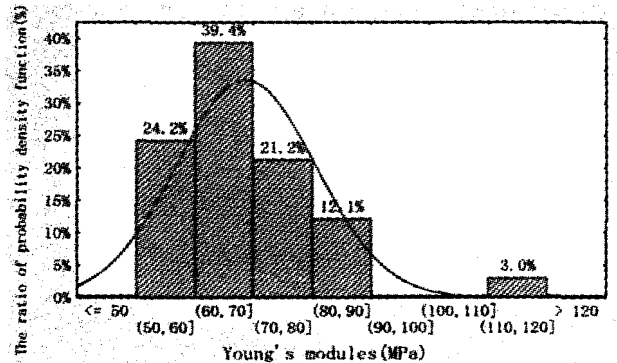

Fig.4 Histogram of Young's modules in the case of Tiger puffers

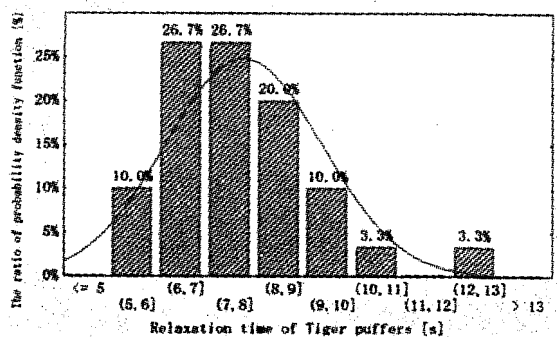

Fig.6 Histogram of relaxation time in the case of Tiger puffers

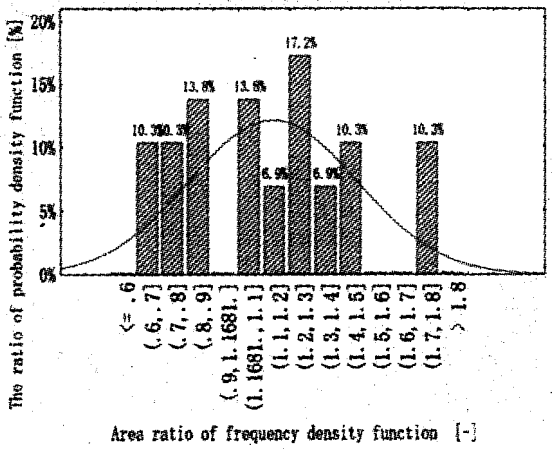

Fig.8 Histogram of area ratio on apparent mass in the case of Tiger puffers 